Oct 1, 1990 - June 30, 1992

\title{
Electronic Transport and Mixed Conductivity in Perovskite Type Oxides
}

Dr. H.U. Anderson, Principal Investigator Ceramic Engineering Department

Dr. M.M. Nasrallah, Co-P.I. Ceramic Engineering Department

Dr. D.M. Sparlin, Co.P.I. Dr. P.E. Parris, Co-P.I. Department of Physics

\section{Electronic Materials Processing and Characterization Institute University of Missouri-Rolla}

Rolla, MO 65401

March 3, 1992

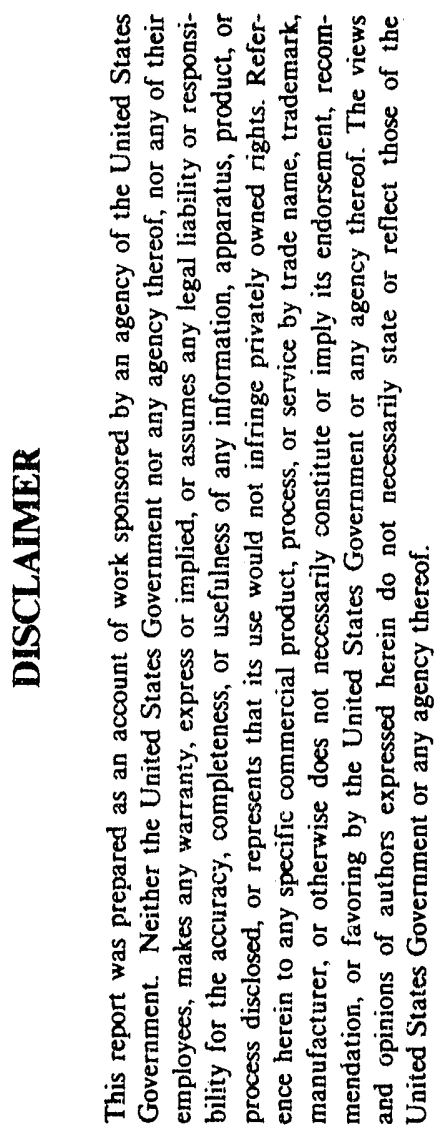

\section{MASTER}




\section{ABSTRACT}

The goal of the investigation presented in this report is to study the inter-relationship between electrical conductivity, oxidation-reduction kinetics, defect structure, and composition of $n$ - and $p$-type binary and ternary transition metal oxides. The experimental part of the investigation included specimen preparation, thermogravimetric measurements, $X$ ray diffraction, thermally stimulated current, DTATGA, optical absorption, transmission electron microscopy, electrical conductivity, and Seebeck measurements. The systems studied or being studied are $\mathrm{LaMnO}_{3}-\mathrm{LaCrO}_{3}-\mathrm{LaCoO},(\mathrm{La}, \mathrm{Ca})(\mathrm{Mn}, \mathrm{Al}) \mathrm{O}_{3}, \mathrm{Y}_{1 \cdot x} \mathrm{Ca}_{x} \mathrm{CrO}_{3}$, $\mathrm{YMnO}_{3}-\mathrm{CaMnO}_{3}$, and $\mathrm{LaMnO}_{3}-\mathrm{CaMnO}_{3}$. Results show:

1. that the anomalous behavior of the electrical conductivity observed in the $\mathrm{La}(\mathrm{Cr}, \mathrm{Mn}) \mathrm{O}_{3}$ system can be explained by a combination of trapping and percolation.

2. that $Y_{1-x} \mathrm{Ca}_{x} \mathrm{CrO}_{3}$ is more stable towards reduction than $\mathrm{LaCr}_{1-x} \mathrm{Mg}_{x} \mathrm{O}_{3}$;

3. that $Y_{1-x} \mathrm{Ca}_{x} \mathrm{CrO}_{3}$ conducts via the adiabatic small polaron mechanism.

4. that $\mathrm{La}_{1-x} \mathrm{CrO}_{3}$ conducts via the nonadiabatic small polaron mechanism.

5. that $\mathrm{La}_{1-x} \mathrm{Sr}_{x} \mathrm{MnO}_{3}$ conducts via the nonadiabatic small polaron mechanism.

6. and that $\mathrm{LaMnO}_{3}, \mathrm{La}_{1-x} \mathrm{Sr}_{x} \mathrm{MnO}_{3}, \mathrm{La}_{1-x} \mathrm{Ca}_{x} \mathrm{MnO}_{3}$ and $\mathrm{Y}_{1-x} \mathrm{Ca}_{x} \mathrm{MnO}_{3}$ appear to contain $\mathrm{Mn}^{+2}-\mathrm{Mn}^{+4}$ pairs which tend to dominate the electrical conductivity

7. that the electrical conductivity of $(\mathrm{La}, \mathrm{Cr})(\mathrm{Mn}, \mathrm{Al}) \mathrm{O}_{3}$ can be explained by a combination of trapping and percolation

8. that $(\mathrm{Y}, \mathrm{Ca}) \mathrm{MnO}_{3}$ and $(\mathrm{La}, \mathrm{Ca}) \mathrm{MnO}_{3}$ conduct via the adiabatic small polaron mechanism

9. that the $(\mathrm{La}, \mathrm{Ca})(\mathrm{Cr}, \mathrm{Co}) \mathrm{O}_{3}$ system shows disproportionation of $\mathrm{CO}^{+3}$ similar to that observed for $\mathrm{Mn}^{+3}$ 
(1) The studies in the $\mathrm{Y}_{1-x} \mathrm{Ca}_{x} \mathrm{CrO}_{3}$ system also are yielding some important results. They are showing that this oxide system is more stable towards reduction than $\mathrm{LaCrO}_{3}$. This suggests that we may have an alternate to $\mathrm{LaCrO}_{3}$ as a high temperature electrode.

Some of the other significant results found for the $\mathrm{YCrO}_{3}$ system are:

a) $\mathrm{Y}_{1-x} \mathrm{Ca}_{x} \mathrm{CrO}_{3}$ conducts via the adiabatic small polaron mechanism. It fits this mechanism better than any oxide that we have found either in the literature or in our previous measurements.

b) With the appropriate additions of $\mathrm{Ca}$ and $\mathrm{Co}, \mathrm{YCrO}_{3}$ can be densified in air at temperatures below $1450^{\circ} \mathrm{C}$ without degradation of stability towards reduction.

c) The thermal expansion coefficient can be increased from 7.7 to $9.5 \times 10^{-\infty} \mathrm{C}^{-1}$ by addition of 0 and 20 mol\% Ca respectively.

(2) The studies on the $(\mathrm{La}, \mathrm{Sr})(\mathrm{Mn}, \mathrm{Cr}) \mathrm{O}_{3}$ system have yielded some significant results which are significantly increasing our understanding of the conduction behavior of perovskite oxides. Results are:

a) conduction occurs via the nonadiabatic small polaron mechanism.

b) the seebeck data suggests that (l.a, Sr) $\mathrm{MnO}_{3}$ contains $\mathrm{Mn}^{+2}-\mathrm{Mn}^{+4}$ pairs which dominate the electrical conductivity. Our data are consistent with $50 \%$ of the $\mathrm{Mn}$ being in the +4 state with little dependence on $\mathrm{Sr}$ content.

c) The electrical conductivity suggests that it depends upon $\mathrm{Mn}$ content. At $\mathrm{Mn}$ concentrations less than $10 \mathrm{~mol} \%$, the $\mathrm{Mn}$ acts as traps for the carriers and the room temperature conductivity decreases by 2 to 3 orders of magnitude. As the $\mathrm{Mn}$ content increases to $30 \mathrm{~mol} \%$ and beyond, the conduction increases hypercolation through the $3 \mathrm{~d}$ band of the $\mathrm{Mn}$.

(3) The studies on the ( $\mathrm{La}, \mathrm{Ca})(\mathrm{Al}, \mathrm{Mn}) \mathrm{O}_{3}$ system show that the conductivity can be related to a site percolation-type model in which small polarons hop between degenerate $\mathrm{Mn}$ sites. Conductivity below the percolation limit is very low and can be attributed to either longer than nearest neighbor hopping or lonic conductivity, while conductivity above the percolation limit increases dramatically due to a connecting path of available $\mathrm{Mn}$ sites which span the crystal. The increase in activation energy for lower $M n$ concentration, along with a systematic 
increase in Seebeck coefficient with decreasing Mn content, seems to imply the suppression of $\mathrm{Mn}^{2+}-\mathrm{Mn}^{4+}$ disproportionation (pairing) through a dependence of site energy upon adjacent site occupancy.

(4) The studies on the $(\mathrm{Y}, \mathrm{Ca})(\mathrm{Mn}) \mathrm{O}_{3}$ and $(\mathrm{La}, \mathrm{Ca}) \mathrm{MnO}_{3}$ systems showed that the electrical conduction appeared to occur via a small polaron hupping mechanism for both systems.

Seebeck coefficient data did not support the traditional assumption that $\mathrm{Mn}$ is present in $\mathrm{Mn}$ perovskites only in the +3 and +4 valence states. The Seebeck data could be explained by allowing for the presence of site-blocking divalent Mn cations; accordingly a new defect model was developed which included the thermally excited disproportionation of $\mathrm{Mn}^{3+}$ into $\mathrm{Mn}^{2+}$ and $\mathrm{Mn}^{4+}$ pairs. Since compositions in $\mathrm{Y}_{1-x} \mathrm{Ca}_{x} \mathrm{MnO}_{3}$ exhibited very slight oxygen activity-dependent behavior as ambient oxygen activity was reduced, several compositions in the system $\mathrm{La}_{1-x} \mathrm{Ca}_{x} \mathrm{MnO}_{3}$ were studied in order that the defect model could be applied to the oxygen-dependent region in manganites. The model was successful in explaining the experimentally observed dependence of oxygen stoichiometry, electrical conductivity, and Seebeck coefficient upon ambient oxygen activity.

(5) The studies in the $(\mathrm{La}, \mathrm{Ca})(\mathrm{Cr}, \mathrm{Co}) \mathrm{O}_{3}$ system indicate that production of $\mathrm{Co}^{4+}$ carries appears to be occurring as the temperature is increased. Since an average B-site valance of $3+$ must exist to maintain electrical neutrality, a pnssible mechanism for this increase in carriers is the thermally driven disproportionation of $\mathrm{Co}^{3+}$ into $\mathrm{Co}^{2+}$ and $\mathrm{Co}^{4+}$. Such a process also accounts for the near-zero high-temperature Seebeck coefficient of $\mathrm{LaCoO}_{3}$ and the partial suppression of the Verwey mechanism with $\mathrm{Ca}$ doping. Thus it appears that $\mathrm{Co}_{0}$ in this system mimics the behavior of the Mn containing systems. 


\section{CONTRIBUTORS TO PROGRAM}

1. G. Carini, Ceramic Engineering Ph.D. candidate, who was supported by this program. He studied the influence of cation stoichiometry and dopants on $\mathrm{YCrO}_{3}$ system. $\mathrm{He}$ received his Ph.D. in December 1990.

2. R. Raffaelle, Physics Ph.D. candidate, studied two path hopping transport in perovskite materials. He was supported by this program and received his $P h . D$. in December 1990.

3. D. Carter is a Ceramic Engineering Ph.D. candidate, who developed our high temperature controlled atm. dilatometer. $\mathrm{He}$ is partially supported by this program and received his M.S. degree in Dec. 1989 and expects to complete his Ph.D. in August 1992.

4. J. Stevenson is a Ceramic Engineering Ph.D. candidate who is studying the $\mathrm{Y}_{1 \cdot x} \mathrm{Ca}_{x} \mathrm{MnO}_{3}$ system. He is supported by this program and completed his Ph.D. in December 1991.

5. S. Sehlin is a Physics Ph.D. candidate who is continuing the work on transport mechanisms in perovskites. He is supported by this program and expects to complete his thesis by May 1992.

6. M. DeBarr is a Ceramic Engineering M.S. candidate who is studying conductivity in the $\mathrm{La}(\mathrm{Mn}, \mathrm{Al}))_{3}$ system. He is supported by other funds and will complete his thesis by December 1991.

7. F. C. Jang is a Ceramic Engineering Ph.D. candidate who is studying the dispersion characteristics of 0.1 to $0.5 \mu \mathrm{m}$ perovskite powders. He is supported by other funding and completed his thesis May 1991.

\section{OTHER CONTRIBUTORS TO PROGRAM}

1. Dr. H.U. Anderson, Curators' Professor of Ceramic Engineering and Senior Investigator, Materiais Research Center, Principal Investigator and Program Director.

2. Dr. D.M. Sparlin, Professor of Physics and Co-investigator. His responsibilities are to perform the low temperature measurements on superconducting oxides, to supervise the DLTS program, and to assist with the electrical conductivity and Seebeck measurements. His years of experience in instrumentation are applied to the design of equipment and experiments for the general program.

3. Dr. Paul E. Parris, Assistant Professor of Physics. He is modelling the conduction mechanisms in the chromite, manganite and cobaltite systems.

4. Dr. Magdi M. Nasrallah, Research Professor of Ceramic Engineering. He is assisting with experimental details and giving guidance in interpretation of results. 


\section{MANUSCRIPTS PUBLISHED OR ACCEPTED FOR PUBLICATION}

R. Raffaelle, H.U. Anderson, D.M. Sparlin and P.E. Parris, "Transport Anomalics in the High Temperature Hopping Conductivity and Thermopower of Sr-Doped $\mathrm{La}(\mathrm{Cr}, \mathrm{Mn}) \mathrm{O}_{3}$ ", Phy. Rev. $13 \underline{43}, 7991-7999$ (1991).

R. Raffaelle, H.U. Anderson, D.M. Sparlin and P.E. Parris, "Evidence for a Crossover from Multiple-Trapping to Percolation in the High Temperature Conductivity of Mw-Doped $\mathrm{LaCrO}_{3}$ ", accepted Phy. Rev. Letters $\underline{6}, 1383$ (1991).

J.H. Kuo, H.U. Anderson, and D.M. Sparlin, "Oxidation-Reduction Behavior of Undoped and $\mathrm{Sr}$ Doped $\mathrm{LaMnO}_{3}$ : Defect Structure, Electrical Conductivity, and Thermoelectric Power", J. Solid State Chem., 87, 55-63 (1990).

M.M. Nasrallah and H.U. Anderson, "Acceptor/Donor Compensation in Rutile", J. Solid State Chem., 90, 373-376 (1991).

H. U. Anderson, M. M. Nasrallah, F. Blum and M. Smith, "Polymeric Synthesis of Perovskite Powders and Films", Proc. of Intl. Conf. on the Chemistry of Electronic Ceramic Materials, NIST 1990, Eds. R. Roth, P. Davies and R. Davies.

G.F. Carini II, H.U. Anderson, D.M. Sparlin and M.M. Nasrallah, "Electrical Conductivity, Seebeck Coefficient and Defect Chemistry of Ca-Doped $\mathrm{YCrO}_{3}$ ", Solid State lonics, 49, 223, (1991).

G.F. Carini II, H.U. Anderson, M.M. Nasrallah and D.M. Sparlin, "Defect Structure, Nonstoichiometry, and Phase Stability of Ca-Doped $\mathrm{YCrO}_{3}{ }^{\text {" }}$, J. Solid State Chem., 94 329-336 (1991).

H.U. Anderson, "Review of P Type; Doped Perovskite Materials for SOFC and Other Applications", Proc. of Workshop on Ceramic Conductors for Solid State Electrochemical Devices, Snowbird, UT, May 12-15, 1991, Eds. A. Khandkar and M. Liu, Solid State lonics, (in press).

J. Stevenson, M.M. Nasrallah, and H.U. Anderson, "Structural and Electrical Characteristics of $\mathrm{Y}_{1 . x} \mathrm{Ca}_{x} \mathrm{MnO}_{3}{ }^{\prime}$, Cer. Soc. Mtg., Cincinnati, OH, April 1991, Symposium on Point Defects, Eds. J. Routbort and T. Mason, Ceramic Transactions, Vol 24.

M. DeBarr, P.E. Parris, D.M. Sparlin, and H.U. Anderson, "Conduction Mechanism in the $\mathrm{La}(\mathrm{Mn}, \mathrm{Al}) \mathrm{O}_{3}$ Series", ibid.

S. Sehlin, P.E. Parris, D.M. Sparlin, and H.U. Anderson, "Evidence for $2+-4+$ Pairing in $\mathrm{La}(\mathrm{Cr}, \mathrm{Co}) \mathrm{O}_{3}$ System", ibid.

R. Raffaelle, J.S. Shapiro, H.U. Anderson, P.E. Parris and D.M. Sparlin, "Anomalous Temperature Dependence of the Seebeck Coefficient for the Substitutionally-Disordered Hopping Conductors ( $\mathrm{La}, \mathrm{Sr})(\mathrm{Cr}, \mathrm{Mn}) \mathrm{O}_{3}{ }^{\prime \prime}$, ibid. 
D.M. Sparlin and R. Raffaelle, "Theoretical and Experimental Implications of Self Compensation in the $\mathrm{RMnO}_{3}$ Perovskite Structure", ibld.

M.M. Nasrallah, H.U. Anderson, and J. Stevenson, "Defect Chemistry and Properties of $\mathrm{Y}_{1-x} \mathrm{Ca}_{x} \mathrm{MnO}_{3}$ ", 2nd International Symposium on Solid Oxide Fuel Cells, Athens, Greece, July 2-5, Ed. S. Singhal, Electrochem. Soc., Pennington (1991).

M.M. Nasrallah, D.C. Carter, and H.U. Anderson, "Liquid Phase Sintering in the $\mathrm{LaCrO}_{3}$ and $\mathrm{YCrO}_{3}$ Systems", Ibid.

F.C. Jang and H.U. Anderson, "Dispersion Studles in the $\mathrm{LaCrO}_{3}-\mathrm{LaMnO}_{3}$ System", 4th International Conference on Ceramic Powder Processing Science, Nagoya, Japan, March 1215, 1991, Ceramic Powder Science IV, Eds. G.L. Messing, S. Hirano and H. Hausner, Amer. Cer. Soc.

F.C. Jang and H.U. Anderson, "Ph effects on the Dispersibility and Setting Behavior of Alumina in Water", ibid.

\section{MANUSCRIPTS PRESENTED, IN PREPARATION, OR SUBMITTED}

H.U. Anderson, M.M. Nasrallah, R. Koc, and D. Carter", Air Sintering of $\mathrm{LaCrO}_{3}$ and $\mathrm{YCrO}_{3} "$, 1990 Fuel Cell Seminar, Phoenix, AZ, November 25-28, 1990.

H.U. Anderson and G. Carini, "Defect Chemistry and Properties of $Y_{1 \cdot x} \mathrm{Ca}_{x} \mathrm{CrO}_{3}$ ", 6th Workshop on Nonstoichiometric Compounds, Tokyo, Japan, December 3-5, 1990.

M.M. Nasrallah, H.U. Anderson, and J. Stevenson, "Defect Chemistry and Properties of $\mathrm{Y}_{1-x} \mathrm{Ca}_{x} \mathrm{MnO}_{3}$ ", 2nd International Symposium on Solid Oxide Fuel Cells, Athens, Greece, July 2-5, 1991.

M.M. Nasrallah, D.C. Carter, and H.U. Anderson, "Liquid Phase Sintering in the $\mathrm{LaCrO}_{3}$ and $\mathrm{YCrO}_{3}$ Systems", ibid.

F.C. Jang and H.U. Anderson, "Dispersion Studies in the $\mathrm{LaCrO}_{3}-\mathrm{LaMnO}_{3}$ System", 4th International Conference on Ceramic Powder Processing Science, Nagoya, Japan, March 12 $15,1991$.

F.C. Jang and H.U. Anderson, "Ph effects on the Dispersibility and Setting Behavior of Alumina in Water", ibid.

D.C. Carter, M.M. Nasrallah and H.U. Anderson, "Properties of Liquid Phase Sintered LaCrO and $\mathrm{YCrO}_{3}{ }^{\prime}$, Ceramic Society Meeting, Cincinnati, $\mathrm{OH}$, April 1991.

J. Stevenson, M.M. Nasrallah, and H.U. Anderson, "Properties of $\mathrm{Y}_{1-x} \mathrm{Ca}_{x} \mathrm{MnO}_{3}$ ", ibid.

M. DeBarr, P.E. Farris, D.M. Sparlin, and H.U. Anderson, "Conduction Mechanism in the $\mathrm{La}(\mathrm{Mn}, \mathrm{Al}) \mathrm{O}_{3}$ Series", ibid. 
S. Sehlin, P.E. Parris, D.M. Sparlin, and H.U. Anderson, "Evidence for $2+-4+$ Pairing in $\mathrm{La}(\mathrm{Cr}, \mathrm{Co}) \mathrm{O}_{3}$ System", ibid.

H.U. Anderson, "Perovskite for Use as Oxygen Separation Membranes", Colorado School of Mines, Sept. 27, 1991.

H.U. Anderson, "Sintering of $\mathrm{LaCrO}_{3}$ Based Compounds", Tonen Corp., Kaioagoe-shi, Japan, Nov. 30, 1990.

P.E. Parris, "Evidence for a Crossover from Multiple Trapping to Percolation in Subsitutionally Mixed Conducting Ceramics", University of Missouri-Columbla, Department of Physics, Condense Matter Physics Seminar, October 22, 1990.

P.E. Parris, "Effective Medium Theory for the Conductivity of Substitutionally-Disordered Binary Lattices", $38^{\text {th }}$ Midwest Solid State Conference, University of Nebraska-Lincoln, November 1990.

P.E. Parris, "Quantum and Stochastic Aspects of Trapping Kinetics in Ordered and Disordered Condensed Phases", Invited talk to be given at March 1991 conference "Models of Nonclassical Reaction Rates", Bethesda, MD.

P.E. Parris, "Theoretical Studies of the Multiple-trapping to Percolation Crossover in Subsitutionally-Disordered Binary Crystals", March 1991 meeting of the American Physical Society, Cincinnati, $\mathrm{OH}$.

P.E. Parris, D.M. Sparlin, and H.U. Anderson, "Studies of the Thermoelectric Power for Subsitutionally-Disordered Hopping Conductors", March 1991 meeting of the American Physical Society, Cincinnati, $\mathrm{OH}$.

P.E. Parris, "On The Theory of The Seebeck Coefficient", Institute for Electronic Materials Processing and Characterization, UMR, November 1990.

P.E. Parris, "On the Theory of The Seebeck Coefficlent Revisited", Institute for Electronic Materials Processing and Characterization, UMR, Febrary 1991.

P.E. Parris, "Multiple Trapping and Percolation in High Temperature Conducting Ceramic Oxides", University of Missouri-Kansas City Physics Colloquium, April 1991.

P.E. Parris, "Low Temperature Exciton Trapping and Reaction Kunetics", University of New Mexico Condensed Matter Physics Seminar, April 1991.

P.E. Pairis, "Crossover from Multiple Trapping to Percolation in High Temperature Conducting Ceramic Oxides", University of New Mexico, Physics Coloquium, April 1991.

R. Raffaelle, H.U. Anderson, D.M. Sparlin and P.E. Parris, "Transport Properties of the Substitutionally-Disordered Hopping Conductors ( $\mathrm{La}, \mathrm{Sr})(\mathrm{Cr}, \mathrm{Mn}) \mathrm{O}_{3}$ Series", American Physical Society Meeting, Cincinnati, OH, March 1991.

P.E. Parris and B.D. Bookout, "Hopping Conduction in Substitutionally-Disordered Binary Solids", American Physical Society Meeting, Cincinnati, OH, March 1991. 
P.E. Parris, A.P. Raffaelle and D.M. Sparlin, "Theoretical Studies of Hopping Conduction in Substitutionally-Disordered Binary Solids", Amer. Cer. Soc. Mtg., Cincinnati, OH, April 1991.

D.M. Sparlin and P.E. Parris, "Conduction Mechanism in the $\mathrm{La}(\mathrm{Mn}, \mathrm{Al}) \mathrm{O}_{3}$ System", Amer. Cer. Soc. Mtg., Cincinnati, OH, April 1991.

R.P. Raffaelle, P.E. Parris, H.U. Anderson and D.M. Sparlin, "Anomalous Temperature Dependence of the Seebeck Coefficient for the Substitutionally Disordered Hopping Conductors (La, $\mathrm{Sr})(\mathrm{Cr}, \mathrm{Mn}) \mathrm{O}_{3}{ }^{\prime \prime}$, Amer. Cer. Soc. Mtg., Cincinnati, OH, April 1991.

D.M. Sparlin, "Small Polaron, Percolation and Disproportionation", University of MissouriKansas City Physics Dept., Sept. 20, 1991.

\section{THESES}

G. Carini, "Electrical Conductivity, Seebeck Coefficient and Defect Structure of Ca-Doped $\mathrm{YCrO}_{3}{ }^{\prime}$, Ph.D. Thesis, Dec. 1990.

F.C. Jang, "Dispersion Behavior of Aluminum Oxide, Lanthanum Manganite and Lanthanum Chromite Powders in Liquids", Ph.D. Thesis, May 1991.

J.D. Steibel, "Sintering of 20\% Calclum-Doped, 20\% Sr-Doped and Undoped LaMnO ${ }_{3}$, M.S. Thesis, May 1991.

M.J. DeBarr, "Investigation of the Conduction Mechanism in La $a_{1-y} \mathrm{Ca}_{y} \mathrm{Al}_{1-k} \mathrm{Mn}_{\mathrm{x}} \mathrm{O}_{3}$ ", M.S. Thesis, Dec. 1991.

R. Raffaelle, "Investigations of Transport Anomalies in $\mathrm{La}_{1-y} \mathrm{Sr}_{y} \mathrm{Cr}_{1 \cdot x} \mathrm{MnO}_{3}$ ", Ph.D. Thesis, Dec. 1990.

J.W. Stevenson, "Electrical and Structural Properties of Compositions in the System $\mathrm{Y}_{1-\mathrm{x}} \mathrm{Ca}_{x} \mathrm{MnO}_{3}$ and $\mathrm{La}_{1-x} \mathrm{Ca}_{x} \mathrm{MnO}_{3}{ }^{\prime \prime}$, Ph.D. Thesis, Dec. 1991.

J.D. Carter, "Sintering Studies on the (La,Sr,Ca)CrO 3 System", Ph.D. Thesis, May 1992. 

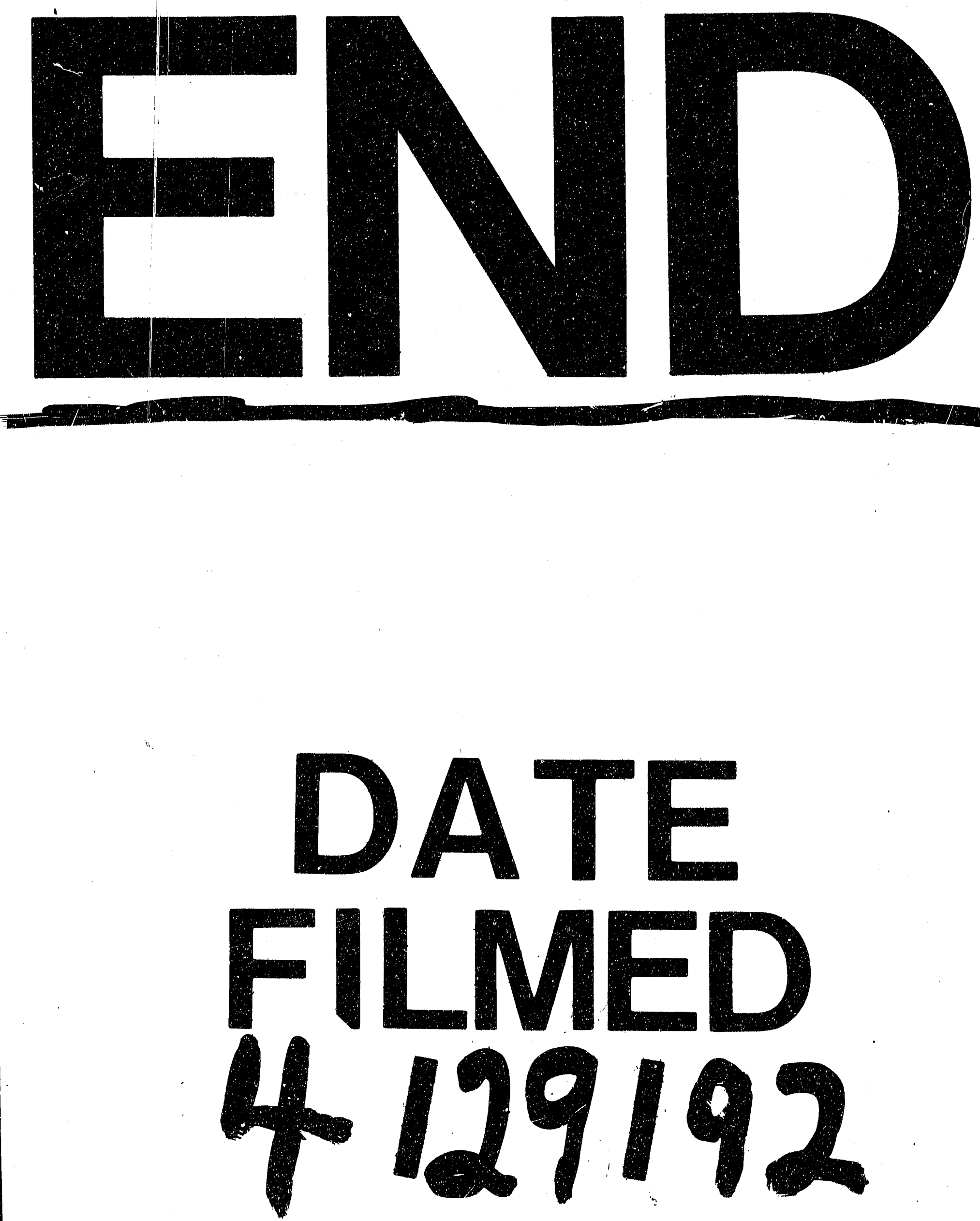

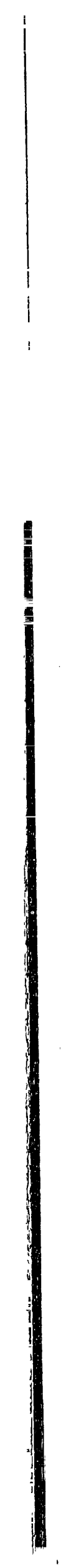